\title{
Does every cell get blood? young students' discussions about illustrations of human blood circulation.
}

\author{
Anna-Karin Westman'1, Karl-Göran Karlsson² \\ ${ }^{1}$ Department of Science Education and Mathematics, Mid Sweden University, Härnösand, Sweden \\ 2," Department of Science Education and Mathematics, Mid Sweden University, Härnösand, Sweden \\ For correspondence: anna-karin.westman@miun.se
}

\begin{abstract}
This article presents a study of how groups of young students discuss illustrations of human blood circulation. Transparency is not an innate quality of illustrations, visual information is always coded and interpretations are always related to culture and context. Results of this study are discussed with reference to Kress and van Leeuwens' theoretical framework on multi-modal communication. Four student groups discussed the human blood circulation with a researcher after the groups had watched an educational film. Data was collected by video recording and an analysis of the group discussions was done by coding the transcripts according to the research questions. The results show how the students mainly discuss human blood circulation on a macroscopic level and that they only partly understand the illustrations from the film. Students showed difficulties to interpret illustrations with a scientific/technical orientation. The students in this study would need more help to find connections between human blood circulation and the content in the film, such as analogies and everyday phenomena, as the results show that the students do not easily connect the different illustrations to each other and they expressed only a few of the scientific ideas from the illustrations in this study.
\end{abstract}

Keywords:educational film, group discussion, human blood circulation, multi-modality

\section{Introduction}

In contemporary society there is an abundance of multi-modal communication. When using visual information in education, the transparency of pictures and models is often regarded as unproblematic. However, transparency is not an innate quality of illustrations and cannot be taken for granted. On the contrary, visual information is always coded and interpretations are always related to culture and context. In education, explanatory illustrations with abstract as well as concrete elements are frequent in for instance textbooks, in oral teaching situations, and in electronic multimedia programs. However, whilst there have been a number of research projects in this domain with older students, studies including primary and pre-school students are rare.

Illustrations are used widely in science teaching and learning, and through science history illustrations have been tools for developing knowledge about science phenomena. Graphs, diagrams, drawings and pictures have been means of assistance in science communication.

This study aims to investigate how young students interpret explanatory illustrations, which are used in science teaching and learning. This can contribute to an increased understanding of gains and losses when illustrations are used as a part of science teaching and learning. The teaching material used for this study was a film about human blood circulation and the research questions were about important scientific ideas regarding human blood circulation, ideas that have proven to be hard for students to grasp in previous research studies. 


\section{Background}

Literacy and Explanatory Illustrations in Science Education

Scientific literacy can be described as an ability to understand basic scientific concepts and facts. It can also be the ability to use different explanatory illustrations, such as symbols, diagrams, graphs and pictures (Lemke, 1998). Kress and van Leeuwen (2006) consider that in natural science or technical contexts it is rare that a natural depiction is the best way to illustrate a phenomenon in the most complete way. An outline in a simplified way or a diagram can contribute to dimensions which describe the phenomena more clearly. Those kind of explanatory illustrations demand qualifications such asobjectivity, abstraction and decontextualisation, and higher education is partly an educationto reach such abilities. Colours do not need to be realistic in a scientific or technical illustrations, but can be established symbolically. According to Kress and van Leeuwen educational material for younger students contains illustrations that combine scientific/technical orientation with a more naturalistic orientation, maybe because the naturalistic depictions are closer to the children's earlier experiences (ibid.).

Concepts in science teaching can be represented in different ways and learners have to be able to connect the different representations. An example is the concept oxygen and the chemical symbol for oxygen. The content of oxygen in air when a person breathes in and out could also be represented in a diagram. Teaching in science varies between the uses of only one mode, e.g. written text, to situations when students are expected to coordinate several modes, e.g. study diagrams, take notes and carry out calculations. By accompanying a student in secondary school through a day of lessons in chemistry and physics Lemke (1998) states that it takes a well-developed capability of scientific literacy to coordinate the different modes, and this should be done at the same time as students are supposed to learn a new content. Johnstone (2009)argues in favour of a chemistry teaching that starts in the macroscopic world and links up with the students' everyday experiences. The teacher should limit the amount of new concepts in teaching according to Johnstone, and he supports his argument with the fact that the working memory needs to both store and process new information. It is interesting to consider the content in educational films in regard to Lemke's and Johnstone's description of students' difficulties in science learning.

Literacy in general is no longer only aquestion of interpreting written and spoken language; today other modes are equally important for meaning making. Scientific literacy calls for an extensive ability to interpret a combination of modes, sincenatural science research and education have, through history, virtually always used explanatory illustrations of different kindstogether with written and spoken language for meaning making. A theory of literacy which includes modes of different kindcan promote an understanding for these explanatory illustrations' roles and on which basis these modesare used.In this article I use the term "mode" as defined by Kress (Kress, 2005):"I use the term "mode" for the culturally and socially produced resources for representation and "medium" as the term for the culturally produced means for distribution of these representations-as-meanings, that is, as messages."

In our case the parts of the film, such as the illustrations, are the modes and the film in its whole is the medium. Kress (2003)advocates a semiotic theory where speech and writing are two modes; gestures, pictures and three-dimensional objects are others. Communication can be carried out by a combination of modes in differentmedia and Kress also emphasizes that in this theory the genre and discourse in which this communication take place will be central. Furthermore the meaning making only gives meaning to the reader (interpreter) and the creator must do an approximation of the reader's meaning making (ibid. p.39).

\section{Students' Difficulties Regarding the Function of Human Blood Circulation}

A biological phenomenon as human blood circulation is difficult to understand for several reasons. It is a complex system, which ranges from sub-microscopic to macroscopic level. It includes organs at the macroscopic level, such as heart and large blood vessels, different cell types at the microscopic level and also molecules at the sub-microscopic level. Children can also encounter problems to make meaning of the system since it is hidden inside the body(Buckley, 2000).Difficulties have been 
documented for 15-16 year old students regarding patterns of circulation, the relation between circulation and respiration and the meaning of a closed circulation system (ibid). Patterns of circulation have also been reported as difficult to understand for10-11 year old students.The difficulties consist of understanding the systemic and pulmonary circulation and being able to interpret a diagram related to the circulation in the body, with red, oxygenated blood and blue, deoxygenated blood(Özgür, 2013). Findings of students' difficulties to understand the closed circulation system is backed up by Sungur et.al. (Sungur, Tekkaya, \& Geban, 2001), who carried out interviews and literature review and describe how 17 year old students' ideas about human blood circulation include ideas of the capillaries open up by the cells or enters the cells as vessels inside the separate cells.

Another study points to the fact that students know more about the organs' position in the body than of their function(Prokop \& Fančovičová, 2006). The researchers let student from the first year in university draw pictures of and answer questions about organ system in the body. In the students' pictures heart and lungs were the most frequent occurring organs, and seem to be the best known. The questions to the students were open questions concerning the function of different organ systems. Though the students drew several organ systems, they could not answer questions about all the systems' functions. Prokop andFančovičová(2006)could not find any statistic relations between students' answers to the questions and if their drawing included the corresponding organ system.The researchers therefore suggest assignments that combine writing with drawing, to find out more about students reasoning about bodily functions.

Many of the mentioned studies refer to an older study, in which the authors selected student difficulties through concept maps and interviews and then constructed a test out of these(Arnaudin \& Mintzes, 1985). This test was then carried out by 495 students from grade five, eight, ten and first year in college. The results show that as students got older they got closer to the scientific idea regarding:

- Structure and function of the blood

- Structure and function of the heart

A smaller progression towards the scientific idea regarded:

- Patterns of circulation

- The relation between circulation and respiration

- Closed circulation

Later research results indicate that the later scientific ideas can still be challenging to grasp for students in different stages of the educational system (Mathai \& Ramadas, 2009; Lee \& Kim, 2014).

Socio-Cultural Perspective on Learning in Science

Learning the scientific ideas can be regarded as a socio-cultural activity. Theories of language, communication and learning can frame the perspectives on a teaching and learning sequence (see for example Bakhtin, Emerson, \& Holquist, 1986; Lemke, 1990; Linell, 2009).In a socio-cultural perspective a group discussion among students can be seen as a cognitive activity, which exists inside as well as between individuals. An example of the perspective is a quote from Paul Thibaultwho states that "semiotics and cognition are distributed among neuro structures, ecosociality and bodily activity" (Linell, 2009).

Learning takes place through interaction with the environment and out of this perspective Mortimer and Scott discuss three steps for teaching(Mortimer \& Scott, 2003). The authors point to the fact that scientific ideas have developed during hundreds of years, and to help the students learn the ideas the science teacher must first make the scientific ideas available in the classroom. Then, with assistance from the teacher, the students can make meaning for themselves out of the ideas. Mortimer and Scott designate this as internalizing, but the term can be misleading and seems to include mental entities as well as a dichotomy between what is inside and outside an individual (Wertsch, 1998). We will therefore use the term appropriation henceforth.Appropriation is suggested as a term for the process of "one taking something that belongs to others and making it one's own" (ibid, page 53). The way of using representations in natural science is needed to be appropriated by the students in this study, it 
is needed to make them able to appropriate the scientific ideas in the educational film. The educational film in the study presented in this article can be compared to the first step for teaching suggested by Mortimer and Scott and the discussion with the researcher and the other students can be compared to the second step(Mortimer \& Scott, 2003). The students encounter scientific ideas about human blood circulation when they see the educational film and afterward they get an opportunity to appropriate those ideas by accomplishing a common assignment and discussing them with each other and with the participating researcher.

\section{Aim and research questions}

The aim of this study is to explore a discussion among students who have seen an educational film and afterwards carry out a drawing assignment and discuss their interpretation of illustrations of the human blood circulation. Special attention is given to analogies to society, the mode of explanatory illustrations and to student interpretation of illustrations typical to natural science context (Kress \& Van Leeuwen, 2006).

Research questions:

- How do the students express the multiple functions of the human blood circulation in respect to the analogies made in the start of the educational film?

- How do the students express the multiple functions of the human blood circulation in respect to the circular pattern and symbolic colours in an illustration from the film?

- How do the students express the relation between an abstract illustration of blood circulation at cellular levelfrom the film and the function of blood circulation at organism level?

\section{Method}

Data Construction

Ten students from year five in Swedish compulsory school participated in the study. The participants were divided into smaller groups during the data collection and they had given their informed consent in advance. First the small groups saw the film together and after the film the students produced a drawing of the human blood circulation and discussed two of the illustrations from the film. The drawing was made on a paper with a pre-printed silhouette of a human. It was given to the students and the student groups also got a paper heart to put in the silhouette. The whole session took about 40 minutes and was video recorded.

Four groups in year five carried out the assignment, two groups with two students and two groups with three students. Jill Robbins has used children's drawing as a mean for a group to establish a common view of a scientific phenomenon (Robbins, 2005)and the method was used in the same way in this study. Kress (2003) emphasizes that selecting one mode will offer specific possibilities and restrictions. As an example drawing the blood circulation of a whole human body can make it hard to describe the circulation in great detail. Data construction of the video recordings started with a transcription of the whole material. Transcriptions were done of both language and speechless events, like gestures and laughter.Drawings were also used for data production. Drawing is a mode that is a well-known cultural tool for students in the Swedish compulsory school and in the school where this study took place the walls were decorated with drawings produced by the students in their studies of different school subjects, not only in art but e.g. geography. This study's drawing assignment was something the students carried out without hesitation.

\section{The Educational Film}

The educational film the students saw was produced in Canada, but has a Swedish speaker voice and isavailable for schools from a Swedish media distribution central(VLC Media, 2009). The target group was students from 11 years, and the film was recommended for students between 11 and 16 years old. It starts with analogies between blood circulation and vehicles as means for transportation, water pipes and garbage trucks in the community. It continues with the structure and function of blood circulation and the content of blood. The filmincludes animations, stills and also sequences of everyday events with people. Many of the animations and stills demonstrate microscopic 
phenomena, others simplified schedules of the blood circulation through the body. A speaker voice guides the viewer through the whole film. The educational film in this study can be described as a multi-modal medium (Kress, 2003), which includes speech, illustrations and animations and the content should communicate the natural science ideas according to the syllabus and the curriculum. Special attention is given to two of the explanatory illustrations(Figure 1 and 2) in the analysis and those two illustrations from the film were also discussed separately after groups had finished their drawing assignment.

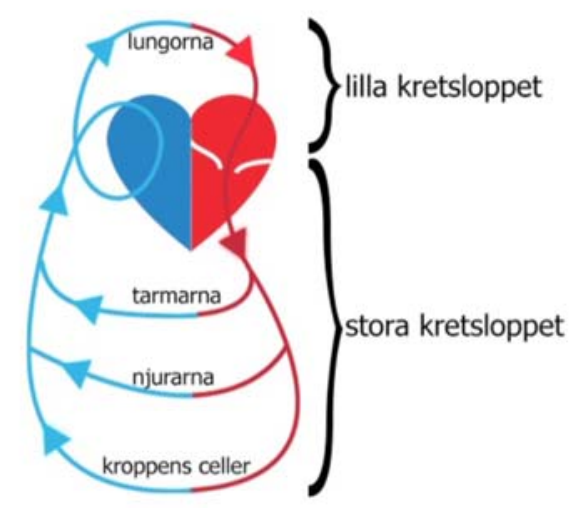

Figure 1 A simplified illustration of the circular pattern of the human blood circulation and its multiple functions from the educational film

(lillakretsloppet $=$ pulmonary circulation, storakretsloppet $=$ systemic circulation, lungorna $=$ lungs, tarmarna $=$ intestines, njurarna $=$ kidneys, kroppensceller $=$ cells in the body)

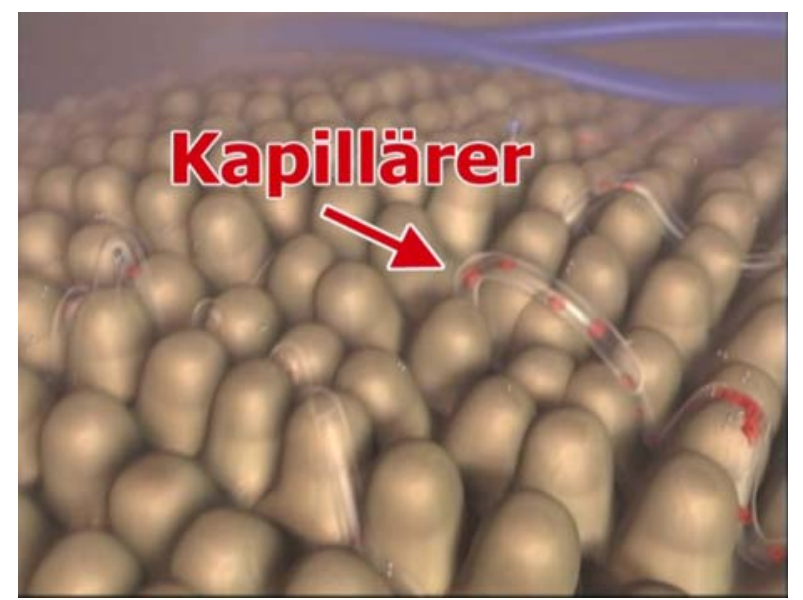

Figure 2 An illustration of capillaries and cells from the educational film (Kapillärer $=$ Capillaries)

The two illustrations from the film were illustrations with a scientific/technical orientation with symbolical colours which illustrated the multiple functions of the blood circulation (Figure 1) and a highly abstract drawing which illustrated the capillaries connection to the cells (Figure 2). Both illustrations belong to the type of illustrations which are common in the natural science context (Kress \& Van Leeuwen, 2006).

\section{Analysis}

The analyses were done by an inductive approach (Derry et al., 2010), where the video of the group discussion first was studied in its whole and afterthat concentrated to the parts where the content corresponded to the research questions. The analysis started by watching the videos in their whole and then draw up flow-charts for each recorded event. Flow-charts of each event were a tool for finding the partswith a content that matched the aim for this study and those parts were then in focus 
for the rest of the analysis. Themethod used here is a modified version of an analysis called whole-topart inductive procedure (Erickson, 2006). A whole-to-part inductive procedure starts with social viewing and re-viewing to find patterns in a material for which there are no strong orienting hypotheses, predictions or theoretical orientations.In this case a research group watched the recordings together and agreed on how to frame the most interesting parts in research questions which fulfilled the aim of this study. The modification of the procedure described by Erickson (ibid.) consisted of a formulation of the research questions by a combination of the results from previous research as presented aboveand the aim for this study. Three researchers studied the video recordings and agreed upon the three research questions. Student discussions were transcribed in their whole. The research questions were then reformulated into seven different codes for categorization of the transcripts from the discussions. The seven codes were:

- Analogies from the film

- Functions of the human blood circulation

- Colours of the vessels

- Content in the pictures

- Design of the circulation

- Organs/organisms

- Cells

Categorisationof quotes corresponding to the codes were done out of the transcripts in the program Atlas-ti(Scientific Software Development $\mathrm{GmbH}, 2014$ ) and one quote consisted of the part of the discussion when the group discussed the subject and ended when the discussion took another turn.

\section{Results}

Two tables are presented as an introduction to the results. The first table, Table 1, presents the frequency of quotes in each of the seven codes that was used during the analysis. The second table, Table 2, gives an overview of how often the quotations co-occurred. The tables are presented to give an overview of the results and the content in the quotes is discussed after the overview and divided into one heading for each research question.

Table 1. Quote frequency divided on the four groups in the study

\begin{tabular}{|c|c|c|c|c|c|}
\hline Code \Group & $D$ andB & $\mathrm{M}, \mathrm{O}$ and $\mathrm{L}$ & $F, T$ and $H$ & $G$ and $E$ & TOTALS: \\
\hline $\begin{array}{l}\text { Analogies from } \\
\text { the film }\end{array}$ & 0 & 2 & 0 & 0 & 2 \\
\hline $\begin{array}{l}\text { Functions of the } \\
\text { human blood } \\
\text { circulation }\end{array}$ & 7 & 10 & 11 & 6 & 34 \\
\hline $\begin{array}{l}\text { Colours of the } \\
\text { vessels }\end{array}$ & 5 & 6 & 3 & 8 & 12 \\
\hline $\begin{array}{l}\text { Content in the } \\
\text { pictures }\end{array}$ & 5 & 9 & 5 & 3 & 22 \\
\hline $\begin{array}{l}\text { Design of the } \\
\text { circulation }\end{array}$ & 2 & 3 & 5 & 7 & 17 \\
\hline Organs/organisms & 2 & 7 & 12 & 1 & 22 \\
\hline Cells & 3 & 2 & 2 & 0 & 7 \\
\hline TOTALS: & 24 & 39 & 38 & 25 & 126 \\
\hline
\end{tabular}

Table 1 shows the number of quotes from the four groups divided into the seven codes used in our categorization. Two codes are much less frequent than others, analogies and cells, and in both cases those quotes come almost solely at the request of the researcher. Examples of both will follow in the excerpts from the discussion later in the text.

Table 2 gives an overview of how often two codes are used in the same quote, e.g. quotes about the multiple functions of the human blood system co-occur most often with quotes about organs or the 
whole organism. The quotes are written horizontally as well as vertically, which result in that the same figure appears twice and empty cells appear in a diagonal through the diagram. One can see that cells co-occur almost exclusively with content in the picture, as a results from the fact that the students only discuss cells when Figure 2 is shown. The most common co-occurrence is when the human blood circulation is discussed at the same time as an organ or the whole organism. There are occasions when the categorization for a quote includes more than two codes, and the total for each code is therefore higher than in Table 1.

Table 2 Co-occurrence of the quotes

\begin{tabular}{|c|c|c|c|c|c|c|c|c|}
\hline & $\begin{array}{r}\text { Analogies } \\
\text { from the } \\
\text { film }\end{array}$ & $\begin{array}{r}\text { Functions } \\
\text { of } \\
\text { the human } \\
\text { blood } \\
\text { circulation }\end{array}$ & $\begin{array}{r}\text { Colours } \\
\text { of the } \\
\text { vessels }\end{array}$ & $\begin{array}{r}\text { Content } \\
\text { in the } \\
\text { pictures }\end{array}$ & 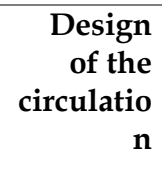 & $\begin{array}{r}\text { Organs/ } \\
\text { organis } \\
\mathrm{m}\end{array}$ & $\begin{array}{r}\text { Cell } \\
\mathrm{s}\end{array}$ & Total \\
\hline $\begin{array}{l}\text { Analogies from } \\
\text { the film }\end{array}$ & - & 2 & 1 & 1 & 0 & 1 & 0 & 5 \\
\hline $\begin{array}{l}\text { Functions of } \\
\text { the human } \\
\text { blood } \\
\text { circulation }\end{array}$ & 2 & - & 13 & 10 & 9 & 14 & 0 & 48 \\
\hline $\begin{array}{l}\text { Colours of the } \\
\text { vessels }\end{array}$ & 1 & 13 & - & 3 & 6 & 5 & 0 & 28 \\
\hline $\begin{array}{l}\text { Content in the } \\
\text { pictures }\end{array}$ & 1 & 10 & 3 & - & 3 & 10 & 7 & 34 \\
\hline $\begin{array}{l}\text { Design of the } \\
\text { circulation }\end{array}$ & 0 & 9 & 6 & 3 & - & 6 & 1 & 25 \\
\hline $\begin{array}{l}\text { Organs/organis } \\
\text { m }\end{array}$ & 1 & 14 & 5 & 10 & 6 & - & 2 & 38 \\
\hline Cells & 0 & 0 & 0 & 7 & 1 & 2 & - & 10 \\
\hline
\end{tabular}

Multiple Functions of the Human Blood Circulation

Discussions of functions of blood circulation co-occur with circular pattern and symbolic colours more often than with analogies from the film. Students discuss both their own picture and the selected picture from the film, but almost never in connection to the analogies from the film. Belowrepresentative examples for each research question are given.

In respect to analogies from the film. Analogies are only mentioned twice and both quotes are from the same group. The analogies are not mentioned spontaneous, but on the request from the researcher (Quote 1).

Researcher: ...but in the film they compare to..., well water pipes, water taps and garbage trucks.

M: yes, the garbage truck is here [points on his own body] and here is a lot of water pipes [makes a moving gesture on his own stomach and laughs]and what's more?

Researcher: Yes, what...

O: busses...

L: and cars...

Researcher: yes...

M: busses and cars, they are like the highway [aiming at their own illustration, in which they called all the lines "highways"]

The students do not express any connection between cars, busses and water pipes and the need for transportation for different functions of the human blood circulation. And after a short part when other things were discussed L mentions one transportation, but this is more related to their own illustration (in which they called the red and blue lines "highways") (Quote 2).

Researcher: and what is the use for this... highway? 
M: it's like this, they can transport a lot of air through it all [aiming at their silhouette] L: ...to all the body part, otherwise you would die.

There are no more discussions about the analogies from the film, no student mentioned the cars, water pipes or garbage trucks spontaneously.

In respect to the circular pattern and symbolic colours.The blood is important, but the reason is more unclearly expressed in the students' utterances. If the purpose is discussed, it is in comprehensive terms as in the quote above or it is expressed as oxygen supply for the organs or the whole organism as in the next quote, when B notes how many red and blue vessels the group has drawn in their illustration (Quote 3).

Researcher: Yes that'sright, what will they all do these [vessels]?

B: Pump blood and like [inaudible] oxygen here [points at his own muscle in the arm] they pump blood in some places.

Researcher: Mm

B: They make [inaudible] oxygen and so...

Figure 1 has symbolic colours of red and blue in each of the illustrated loops and all groups express an understanding of how the colours represent oxygenated and deoxygenated blood. All the groups also have discussions about the colour of the vessels during the assignment (Table 1). How the oxygen is useful for the organism is not discussed, but the need for oxygen is obvious to all the participants (see e.g. Quote 2 and 3). The exchange of gases in the lungs is also a process that is known, an example is the discussion in the following quote (4).

L: the blood, it should help out... eh, eh, the breathing no I don't know...

Researcher: Yeah, that's right, what was it about the breathing?

M: the breathing, you draw in air, then the vessels pick up, and then it goes further, eh eh

L: it was me who...

Researcher: One at a time then.

L: okay, it [the blood] goes off to the lungs and then to the heart, which pumps it out to the body, and then, you like, breathe it out, or I don't know...

Researcher: what do you breathe out?

[All in in chorus]: carbon dioxide

Other functions of the blood circulation are not mentioned by the students unless the researcher asks for more information about the need of our body. Then the students talk about different needs such as water, vitamins and energy.

The multiple functions of the blood are not readily mentioned by the students in the discussion of the illustration of the blood circulation from the film (Figure 1). The discussion follows the question from the researcher of why the three loops are labelled "intestines", "kidneys" and "cells of the body" (Quote 5).

Researcher: [...] Yes, but why do you think they have chosen these specific lines? The line for the intestines, kidneys and cells of the body?

D: Maybe they need most air?

Researcher: Yes, yeah they need...

B: Or they help to pump all the blood out [show with his hand over the silhouette, shrug his shoulders]. I believe in D most... actually.

Researcher: ...'cause that's where the air is most needed? [Looks at D, who nods.]

Once again the need for air is what the students readily come to think of. Another group answered by reading from the illustration (Quote 6). 
F: yes, I thought that the heart goes to them all and the small loop it's up there, so it's the lungs, it belongs to the lungs, but the large loop belongs to the intestines, kidneys and the cells of the body. I don't understand the cells of the body.

H: But it's like, like all you have.

Researcher: [to $\mathrm{H}]$ what did you say?

$\mathrm{H}$ : The cells, it's like what you got in your whole body.

Students in this study do not discuss how Figure 1 is a simplified illustration of the circular pattern of the human blood circulation and its multiple functions.

The circular pattern from Figure 1 is only discussed as arepresentation of the different parts where the oxygen is needed and not as parts with other functions. Even if the researcher asks more questions about the illustration, they still keep their discussion on a superficial level (Quote 7).

Researcher: But I am thinking of: why do they sayit'sone loop [shows with her hands], that's the lungs and then it's another loop, that's the intestines, kidneys and the cells of the body.

T: Maybe because the lungs are so big?

$\mathrm{H}$ : And maybe they need an especially large amount of blood?

F: What, what did you say?

H: Maybe they need as much blood as the rest of the body or something like that?

On a question about the kidneys it seems like the participants know something about the kidneys (Quote 8).

Researcher: Kidneys, why have they written kidneys?

F: Kidneys, what were kidneys (now again)?

$\mathrm{T}$ : What are kidneys?

$\mathrm{H}$ : It is where the pee comes from.

Still they do not express any connections to the blood circulation and the explanatory illustration. Another group suggests an explanation which indicates a mutual connection between blood and the organs (Quote 9).

B: it has to do so the intestines survive and transport..., take care of all the nourishment you get.

Researcher: It is connected to the nourishment.

The picture (Figure 1) in itself is not readily interpreted by the groups, and contributes also to some confusion. First quote is from $\mathrm{L}$ who looks at the picture, when it is discussed after they finished their drawing (Quote 10).

Researcher: [looks at the screen] here they have made a picture, they do not have as many lines as you [group laughs], but they have some lines. And you see the heart in the middle [shows a heart with her hands] and it goes some lines down here [shows with her fingers]intestines, kidneys and cells of the body it says. And up here, it says the lungs.

L: we did not havethem above...

Another student expresses a similar interpretation. When E looks at Figure 1, her utterance reveals a physical interpretation of the illustration (Quote 11).

E: It goes to different parts of the body, like where it says it goes to intestines and kidneys and so on...

Researcher: mm

E: and so it goes up to the brain so it gets oxygen.

In the picture it is written "lungs" on the upper loop, but the comment from $\mathrm{E}$ indicates that she interprets the upper loop to go up in the head. She does not speak of the lungs or the two parts in the 
human blood circulation. The picture is a scientific illustration which displays more than one function of the blood circulation, but which does not succeed to communicate all of these to the students in this study.

$\mathrm{D}$ and $\mathrm{B}$ start their drawing by taking one pencil each, $\mathrm{D}$ takes the blue and $\mathrm{B}$ takes first the black and the red pencil.B draws lungs with a black pencil. He also draws red vessels from the heart and out to the rightlung (Quote 12).

B: [starts drawing with a black pencil] now it will be very ugly lungs, so, there is one and there's the other. They are little differently shaped, it's so you get room for that [points at the heart]

Researcher: Yes...

[Short discussion when B wants D do draw.]

Researcher: yes okay, what happens there [in the lungs]?

B: like, pumping out and then it pumps up [show a large and then a shrinking heart with his hands] so it goes like everywhere and up here.So and then it should be blue everywhere also D.

D: here? [D points with the blue pencil]

B: Yes, just draw some lines.

Researcher: What is the difference between the red and the blue?

$\mathrm{B}$ : The red is oxygenated, but the blue does not have, like, any oxygen at all. [D has finished drawing blue lines] that's there, now I will do the same here [draws in lung number two, D fills in with blue lines] and then we should make large ones to the legs [draws into the right foot] it was large ones into the feet and arms [draws a red line back to the heart and looks at the researcher].

Nothing is expressed about how the oxygen is transported out to the tissues of the body or how the lungs oxygenate the blood in the pulmonary circulation. None of the groups of students express anything about this and none of their own drawings illustrate this (e.g.Figure 3).

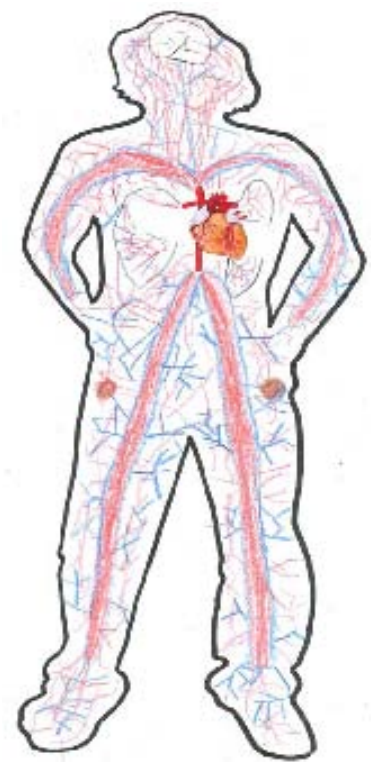

Figure3.B and D's own arawing of the human blood circulation

In two of the four groups the students choose to draw two loops out and back to the heart, one red and one blue. The other two groups draw vessels like they are drawn in the films illustration (Figure $4)$. 


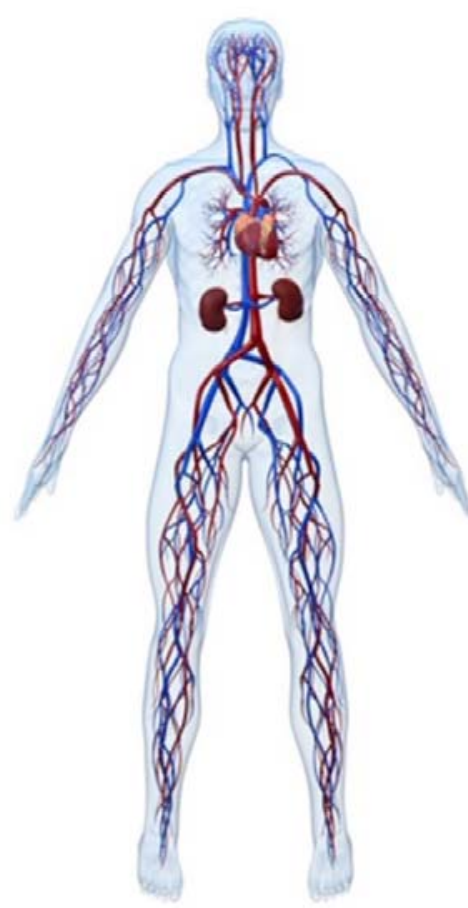

Figure4.An illustration of the human blood circulation from the educational film

Either their drawings have blue and red vessels which end in the end of the legs and arms of the silhouette like D and B or they have separate red and blue circulation.The illustration from the film is also the illustration the students mention afterwards, when the researcher asks if there is any illustration they remember especially well.

Functions of the Human Blood Circulation at Organism Level and Cellular Level

Human blood circulation is discussed in terms of tissues, organs and the whole organism by the students as they draw their illustration of the circulation. Students' discussions of the cells' demands for substances from the blood are rare, and when they are discussed they are faintly outlined. One typical quotation is when T, F and H draw their illustration (Quote 13).

Researcher: Now you have blood in the arm and in both feet...

[Unrelated comment]

F: but here you know, you got blood in the other arm too

T: Do you have blood in the brain, I don't know that?

F: But of course you have, don't you understand that?

$\mathrm{T}$ : Yeah, but then it has to be blood here [points at the head].

F: Yes, but draw it then.

Researcher: Yes, but why do you need it?

F: Yeah, but otherwise you would die.

Students' talk about the multiple functions of human blood circulation concerns solely phenomena on the organ/organism level. The need of blood is expressed in a similar way here as in quote 2, "otherwise you die". The students do not elaborate their argument any further and there is no cooccurrence of functions of the human blood circulation and cellular level (Table 2).

In their discussions the four groupsdiscuss the needs of the body and the discussions are almost entirely on organ or organism level. The students hold on to explanations on the macroscopic level, even when they get questions about the purpose of the blood circulation from the researcher (Quote 14). 
Researcher: What shall the blood do when it reaches the foot?

L: Yeah, but otherwise you won't get any movement there, sort of?

In the same manner other students talk about how the blood circulation makes the brain, muscles or "all the body parts" function or move, or just express that "otherwise you would die". When they look at the illustration of the capillaries and the cells (Figure 2) they do not readily think of the cells. After a question about where in their body they think the theme of the illustration could be, two of the students suggest a lot of places (Quote 15).

D: Maybe skeleton?

B: Maybe skin?

$[\ldots]$

Researcher: Maybe skeleton or skin. Why do you think it is so many balls like this [shows a row of balls with her hands]? What is it... what do you think they want to show? What do you think B?

B: I don't know it looks quite strange.

Researcher: Yes [laughs] what do you think D?

D: Eh, I don't know.

B: No, I don't know what it is.

Researcher: No, do you think there is anything like this in your... own body?

B: Noo...

D: No, I don't know.

B: Maybe it is the intestinal villi?

Researcher: Yes, exactly, that's what they want to show. It is even all the cells they want to show. The ones which were hundred thousand billions, around them all are the capillaries, the smallest vessels [B nods] and then every cell can get what it needs from the blood.

B: Does every cell get blood?

Researcher: Yes.

B: What? It is really hard work.

The discussion in another group shows a similar pattern, $\mathrm{M}$ first suggests that the illustrations show the skin, and then L continues to suggest other places in the body for which the picture can be an illustration (Quote 16).

L: Yes, ordinary knobs. They are in the stomach aren't they..?

M: I don't know, I have never seen it before.

L: Or cells, kind of...cells?

Researcher: Yes, it is really cells they want to show.

M: I was just about to say that, it is cells.

Researcher: Why is it a drawing do you think, why haven't they just taken a picture of them?

M: 'Cause they are so small.

L: Really, have they drawn that? Have they drawn that?

The students have ideas about the cells. Like $\mathrm{L}$ in the quote above and also like $\mathrm{H}$ in Quote 6. Students in this study have all heard about cells. They express that cells are in the whole body, the body is cells and that cells are very small.

\section{Discussion}

The four group discussions present common patterns. One is that analogies from the film are almost absent from the discussions. One reason could be that they are presented in the beginning of the film and do not readily come to the student minds. Contradictory to this suggestion for an explanation are the quotes when the analogies first are mentioned by the researcher (Quote 1). Not even then do the studentsexpress the similarity between the need for different transportation systems in our society and the multiple functions of the circulation. 
The educational film emphasizes the blood circulation's multiple transport functions more than once. Functions of the human blood circulation are frequently discussed by the students (Table 1), but with a closer look at the quotes it is the oxygen supply that is the only evident transport for the students. The discussions concern the colour of the vessels and the content in the illustrations, and it is often in their own illustration (Table 2). The transport of nutrients is mentioned after a while in the subsequent discussion concerning Figure 1. Students in this study very seldom express an appropriation of the scientific idea of the multiple function of the human blood circulation. An explanatory illustration is in this case a mode which is not so easily interpreted by these students and there is no sign of appropriation. When the students draw their own illustration they all end up more or less like Figure4, and just like B and D they use the red and blue pencils (Quote 12). No groups discuss the connection between the red and the blue vessels, but they all know that red is oxygenated and blue deoxygenated blood. In this case the explanatory illustration is a mode which is not sufficient to communicate the scientific idea. Previous research has revealed difficulties for student to grasp the scientific ideas about the relation between circulation and respiration and also about closed circulation(Arnaudin \& Mintzes, 1985; Buckley, 2000). The educational film in this study illustrates these ideas by e.g. Figure 1. The students distinguish between pulmonary circulation and systemic circulation in their discussions, they know of the special purpose for the lungs and express this for example in their drawings (Figure 3). Only after some discussions with the researcher they express ideas regarding function of other organs, and then they connect only nutrient transport to blood circulation.The difficulties to appropriate the meaning of patterns of circulation are in accordance with previous research (Buckley, 2000; Özgür, 2013). From the utterances from two students(quote 10and 11) there also seems to be a risk for misunderstanding of Figure 1 dependent on the location of the pulmonary system. A part of science education is described by Kress and van Leeuwen(2006)as partly a practice in objectivity, abstraction and decontextualisation. The educational film here has illustrations which demand a lot of abstraction, Figure 1 is one example. The illustration contains a lot of information about the function of the blood circulation, but the students have problems in interpreting the different parts. The fact that oxygen is taken up and that carbon dioxide is given off is known by quite a few students (e.g. Quote 4), but why the kidneys or the cells of the body are in the picture is unclear. The kidneys and the cells of the body are discussed like isolated systems by the students and this supports the results fromProkop and Fančovičová(2006). Still they express some knowledge about the function of the kidneys, but not without some questioning from the researcher (Quote 8). Here the explanatory illustration has a possibility to work as a mode which can communicate the scientific idea of functionsin human blood circulation.Apparently the scientific idea of the human blood system's multiple functions has not yet been appropriated by the students in this study.

Thestudents' illustrations are similar to the illustration of the whole body's circulation from the film (Figure 4). When they are questioned about which illustration they remember best from the film, Figure 4 is the most common answer. The film does not explicitly connect capillaries to the whole body's blood circulation and the function of the capillaries is not known by the students. The students' illustrations, just as Figure 4, displays red vessels out from the heart to a leg or an arm and blue vessels back into the heart again. Together with the utterances from the students (e.g. Quote 3) the idea they express is one of organs or body parts being supplied with blood and its content. This is also supported byearlier research, in which results show difficulties for student to grasp the idea of a closed circulation system (Buckley, 2000).

Interpretation of scientific illustrations needs practice and Figure 2 is too difficult to interpret for the students in this study. It demands a capability of abstracting, to make meaning out of the tubes and balls in the illustration. Explanatory illustrations is a mode which can be very demanding when it comes to phenomena on a cellular level and in this it needed a lot of additional support for meaningmaking. The students in our study do not clearly express the scientific idea of blood circulation to and from every cell as the central part of transportation in our body and maybe this is not so strange as their expressions often concern the whole body, not as a building of cells, but as one unit with certaindemands. 


\section{Conclusions and Implications}

Visual communication is always coded and it seems transparent due to the fact that we already know the code (Kress \& Van Leeuwen, 2006). It is obvious also in this study. Some content in the illustrations are overlooked by the students, such as different functions of the blood circulation. An important partof teaching and learning science is to learn how to interpret different explanatory illustrations and this needs practice.

The educational film here includes both naturalistic and scientific/technical illustrations and has a potential to give students an opportunity to increase their ability to interpreta combination of modes to get one, coherent picture of the scientific ideas, an ability that is needed for science studies (Lemke, 1998). The combination of naturalistic and scientific/technical illustrations in the film can also give an opportunity to overcome the difficulties to make meaning for the students due to the fact that the system is hidden inside the body (Buckley, 2000).Everyday phenomena, as analogies to functions in society, physical exercise and visits at a care centre, are mixed with scientific illustrations in the film. The students in this study would need more help to find connections between human blood circulation and the analogies, scientific illustrations and everyday phenomena, as the results show the students do not easily connect the different illustrations to each other and expressed only a few of the scientific ideas from the illustrations in this study. The oxygen demand is the only function of the blood circulation that is clearly manifested by any student. A suggestion would be more clearly expressed connections during the film, how the analogies and everyday phenomena are connected to Figure 1 could be one example of how this can be more distinctly expressed. Another could be how Figure 1 and Figure 4 are connected, that might avoid confusions of how the loops areplaced in the picture. A third suggestion would be to emphasize how the naturalistic illustrations are connected to the illustration of cells and capillaries.

Another conclusion is that the oxygen transport pattern is not necessarily clear to the students just because they know the meaning of the symbolic colours in the illustrations. The students find no reason to explain the cellular function of oxygen in the human body when they are reasoning only on the macroscopic level. It could be considered sufficient to understand the human blood circulation on the organ and organism level for young students or otherwise there is need for challenging questions about the details of the oxygen demandto make them switch to a reasoning on a cellular or molecular level. The human blood circulation is a complex system and in our opinion it is enough for young students to appropriate the idea of the multiple functions of the human blood circulations on a macroscopic level. This could have been done in the film by a clearer connection between the analogies from the society to the abstract scheme in Figure 1.

According to Johnstone (Johnstone, 2009) and his reasoning about chemistry teaching, it is possible to apply on how the students in this study treat the concept cell. He recommends teaching to start in the macroscopic world and link up with the students' everyday experiences. Students in our study discuss blood circulation mostly as a macroscopic event, aiming to supply organs and body parts with necessary substances (especially oxygen). In their discussions it is obvious that they have heard of cells, and they know something about where they exist and how small they are. This is important to know when the cell theory should be presented to students, whether it is in aneducational film or any other part of their science studies. A suggestion is that this could be done when the students are older, it could be enough to appropriate the idea of more functions than oxygen supply for the students in this study. The students express the supply to our body on a macroscopic level; they do not see the supply to cells as an important purpose for the blood circulation and need an explicit marked connection from the macroscopic level to the cell level. A suggestion for teaching materials such as the film in this study is to add some illustrations of the kind that Kress and van Leeuwen describes, illustrations that combine scientific/technical orientation with a more naturalistic orientation (Kress \& Van Leeuwen, 2006). The utterances from students in this study confirm his suggestion that the naturalistic depictions are closer to the children's earlier experiences.

To sum up, the scientific ideas of the human blood circulation system are many and these cannot be quickly appropriated by young students. Students' everyday experiences are good starting points and 
the teaching and learning can then start by taking place at a macroscopic level. The educational film in this study has potential to become an even better teaching and learning tool if the connections to known everyday functions in society are clearly connected to multiple functions in the blood system and then the ground is prepared for an introduction of the cell theory later in this students' education.

\section{Acknowledgement}

The work reported in this paper was supported by the Swedish Research Council as part of the project Meningsskapande illustrationer? (Illustrations making meaning?), registration number 20095995.

Ethical approval: All procedures performed in studies involving human participants were in accordance with the ethical standards of the institutional and/or national research committee and with the 1964 Helsinki declaration and its later amendments or comparable ethical standards. Informed consent was obtained from all individual participants included in the study.

\section{References}

Arnaudin, M. W., \& Mintzes, J. J. (1985). Students' alternative conceptions of the human circulatory system: A cross-age study. Science Education, 69(5), 721-733.

Bakhtin, M. M., Emerson, C., \& Holquist, M. (1986). Speech genres and other late essays Austin: University of Texas Press.

Buckley, B. C. (2000). Interactive multimedia and model-based learning in biology. International Journal of Science Education, 22(9), 895-935.

Derry, S. J., Pea, R. D., Barron, B., Engle, R. A., Erickson, F., Goldman, R., et al. (2010). Conducting video research in the learning sciences: Guidance on selection, analysis, technology, and ethics. The Journal of the Learning Sciences, 19(1), 353.

Erickson, F. (2006). Definition and analysis of data from videotape: Some research procedures and their rationales. In J. L. Green, G. Camilli, E. Grace, A. Skukauskaitçe \& E. Grace (Eds.), Handbook of complementary methods in education research (pp. 177-192)

Johnstone, A. H. (2009). You can't get there from here 1. Journal of Chemical Education, 87(1), $22-29$.

Kress, G. R., \& Van Leeuwen, T. (2006). Reading images: The grammar of visual design (Second ed.) London: Routledge.

Kress, G. R. (2003). Literacy in the new media age London: Routledge.

Kress, G. (2005). Gains and losses: New forms of texts, knowledge, and learning. Computers and Composition, 22(1), 5-22.

Lee, S., \& Kim, H. (2014). Exploring secondary students' epistemological features depending on the evaluation levels of the group model on blood circulation. Science \& Education, 23(5), 1075-1099.

Lemke, J. (1998). Multimedia literacy demands of the scientific curriculum. Linguistics and Education, 10(3), 247-271.

Lemke, J. L. (1990). Talking science: Language, learning, and values. New Jersey: Ablex Publishing Corporation.

Linell, P. (2009). Rethinking language, mind, and world dialogically: Interactional and contextual theories of human sensemaking. Charlotte, NC: IAP.

Mathai, S., \& Ramadas, J. (2009). Visuals and visualisation of human body systems. International Journal of Science Education, 31(3), 439-458.

Mortimer, E. F., \& Scott, P. (2003). Meaning making in secondary science classrooms Philadelphia: Open University Press.

Özgür, S. (2013). The persistence of misconceptions about the human blood circulatory system among students in different grade levels. International Journal of Environmental and Science Education, 8(2), 255-268.

Prokop, P., \& Fančovičová, J. (2006). Students' ideas about the human body: Do they really draw what they know. Journal of Baltic Science Education, 2(10), 86-95.

Robbins, J. (2005). 'Brown paper packages'? A sociocultural perspective on young children's ideas in science. Research in Science Education, 35(2-3), 151-172.

Scientific Software Development. (2014). ATLAS.ti (7.5.7 ed.). Berlin: GmbH.

Sungur, S., Tekkaya, C., \& Geban, Ö. (2001). The contribution of conceptual change texts accompanied by concept mapping to students' understanding of the human circulatory system. School Science and Mathematics, 101(2), 91-101.

Blodet och blodomloppet. VLC Media (Director). (2009).[Video/DVD] Canada: Solfilm Media AB.

Wertsch, J. V. (1998). Mind as action Oxford University Press, USA. 